\title{
Morphological and anatomical features of Bauhinia vahlii Wight \& Arnott. grown in Egypt
}

\author{
Ahmed Hassan Elbanna*, Engy Abdel-hamid Mahrous, Amal El-Sayed Khaleel, Taha Shahat El-alfy \\ Department of Pharmacognosy, Faculty of Pharmacy, Cairo University, Kasr El-Aini Street, 11562, Egypt.
}

\begin{tabular}{l} 
ARTICLE INFO \\
\hline Article history: \\
Received on: 01/08/2016 \\
Revised on: 09/09/2016 \\
Accepted on: 08/10/2016 \\
Available online: 28/12/2016 \\
\hline Key words: \\
Bauhinia vahlii, Phanera \\
vahlii, leaf, stem, \\
macromorphology, \\
micromorphology, hair.
\end{tabular}

\begin{abstract}
Leaves and stems of plants of genus Bauhinia, family Fabaceae subfamily Caesalpinoideae, have been used as folk remedies for treatment of numerous health problems mainly diabetes. The genus is famous for the characteristic camel's foot shape of its leaves and bearing flowers ranging from white, yellow to purple. The shape and size of both flower and leaf are essential for species characterization. This study targets the morphological and histological profiling of Bauhinia vahlii Wight \& Arnott. due to its recently evidenced biological importance. Morphologically, B. vahlii can be distinguished by being a huge evergreen climber with numerous pairs of coiled revolute tendrils. Its branches bear numerous large bilobed hairy leaves and white flowers that turns buff by time. The flowers show three long fertile stamens and two short staminodes. The commonly used parts, leaves and stems, were subjected to a deeper investigation. Microscopically, they are characterized by long non-glandular hairs with three small basal cells and an elongated distal one and that are rare in Caesalpinoideae. B. vahlli was recently segregated into a separate genus; Phanera based on the presence of tendrils, nature of its flower's androceum and phylogenetic data.
\end{abstract}

\section{INTRODUCTION}

Bauhinia is a genus of trees or shrubs that belongs to the legume family; Fabaceae under its subfamily Caesalpinoideae. These plants are widely distributed in warmer parts of the world including Africa, Asia and South America being commonly known as "cow's paw", because of the characteristic shape of their leaves. They were named after two Swiss botanists, the Bauhin brothers (Allen and Allen, 1981). Their leaves and stem barks have been used frequently in folk medicine as remedies for the treatment of diabetes, infections, pains and inflammatory processes and have been confirmed through numerous biological studies (Cechinel, 2009). Accorging to Baily (1953) and Sambamurty (2005) genus Bauhinia comprises over 550 tropical trees, shrubs and climbing species. It is distinguished by the bifid (bilobed) leaves with showy flowers ranging from white, yellow to purple. The leaves are simple,

* Corresponding Author

Email: ahmed.elbanna @ pharma.cu.edu.eg broad, entire or 2-lobed apically. The leaf base is swollen and pulvinate. The flower's corolla consists of five somewhat unequal petals that are usually narrowed into a claw. Stamens are 10 in number but sometimes reduced even to 3 and perhaps bearing sterile filaments. The number and infertility of the stamens are important characters in species identification (Baily, 1953; Sambamurty, 2005).

Bauhina vahlii Wight \& Arnott., also known as Bauhinia racemosa Vahl. and Phanera vahlii Wight \& Arnott. (Bandyopadhyay, 2008), is a huge climber native mainly to India (Parrotta, 2001; Wight and Arnott, 1834) and has been cultivated as an ornamental plant in different regions including Egypt. The name Phanera vahlii was suggested by some recent taxonomic approaches that segregated the species $B$. vahlii into a separate genus, Phanera based on accumulated phylogenetic data obtained from sequencing the plastid trnL-trnF region for 85 species and verification of presence or absence of the plastid $r p l 2$ intron (Sinou et al., 2009) in addition to morphological differences summarized by Wunderlin (2010). 
Its stem bark exhibited anti-inflammatory and acute antihyperglycemic activities (Das et al., 2012) where its leaves showed both in-vitro anti-oxidant and anti-hyperglycemic potentials (Elbanna, 2015; Sowndhararajan and Kang, 2013) and appeared to be rich in different quercetin flavonoids (Elbanna et al., 2016). This study aims to characterize the species B. vahlii from other Bauhinia plants based on its morphological features and histological composition focusing mainly on the most studied and commonly used organs among the genus; leaf and stem.

\section{MATERIALS AND METHODS}

\section{Plant material}

Sample leaves and stems of B. vahlii Wight \& Arnott. were collected in May from Mohammed Ali museum's garden, Kasr Al-Aini, El-Manial, Egypt. The plant identity was authenticated by a senior botanist; Dr. Mohammed El-Gebaly, National Research Center, Giza, Egypt with a voucher specimen (No. 11-6-2013s-1) deposted at the Herbarium of Pharmacognosy Department, Faculty of Pharmacy, Cairo University.

\section{Morphological and anatomical studies}

Samples of the stems and leaves were separated and examined either fresh or after keeping in $70 \%$ ethanol containing $5 \%$ glycerol, as well as after being dried and reduced to fine powder. The morphological features were examined by naked eye and photographed using SAMSUNG Galaxy Note II phone camera (8-megapixel, fixed f/2.6 aperture with a focal length of $3.6 \mathrm{~mm}$, day light, low ISO and high shutter speed). A ruler was utilized for measurements of lengths and widths of ten samples. Histological samples were prepared by free hand sections in the leaf lamina, leaf petiole and stem, according to techniques described by (Kraus and Arduin, 1997). Light microscope image analyzer, Leica DMLB, connected to Leica JVC digital 0.5" CCD camera and Leica QWIN software (Wetzlar, Germany) was utilized for examination of all histological samples.

\section{RESULTS AND DISCUSSION}

\section{Morphological investigation of Bauhinia vahlii Wight \& Arnott.}

B. vahlii is an evergreen tree (Fig. 2) that grows up to 20$25 \mathrm{~m}$ with twisted climbing branches by means of tendrils. The branches bear numerous large bilobed dark green leaves and white flowers that bloom from the end of April till the middle of June. After the flowering period, most of the flowers wither while some produce large woody brown legumes.

\section{The Flower (Fig. 1)}

The plant bears many axillary raceme inflorescences, each is composed of 20-35 flowers, mostly in the bud form with three or more fully developed flowers. The flowers are large on long cylindrical pedicles, white in color turning buff by aging, zygomorphic and when fully expanded they are 10-12 cm long and
4-5 $\mathrm{cm}$ wide. The calyx is densely hairy and formed of five united green sepals forming two lobes; one lobe consists of two united sepals while the other is formed of the three remaining sepals. The corolla consists of five densely hairy white petals with a standard petal enclosed within the lateral ones (wings), a common morphological phenomenon for subfamily Caesalpinoideae (Fernald, 1970, Samuel and Arlene, 1979). The androecium consists of three free long fertile stamens and two small infertile staminodes. Recenlty, some taxonomists shifted B. vahlii under a separate genus, Phanera, based on its number of fertile and infertile stamens in addition to other morphological differences (Wunderlin, 2010). The gynoecium consists of one pistil with a yellowish densely hairy monocarpellary ovary. Its style is long, red in color, densely hairy and ends with a green stigma.
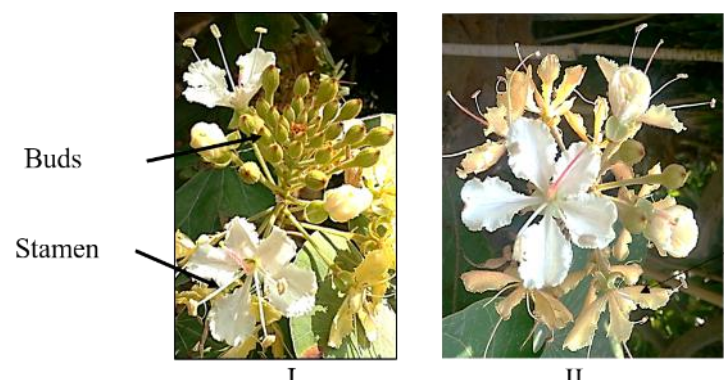

Aged

flower
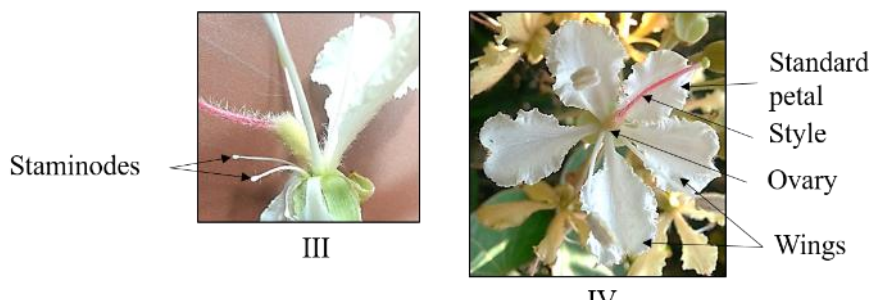

Fig. 1: Photographs of the inflorescence and separate flowers of B. vahlii I: The inflorescence, II: Young and aged flowers, III: Staminodes, IV:A fully developed flower

\section{The stem (Fig. 2 and 3)}

The main stem (trunk) (Fig. 2: I) is hard, solid and cylindrical with thick brown cork showing longitudinal fissures and transverse cracks. It grows obliquely or vertically for about $50-70 \mathrm{~cm}$ then continues mainly horizontally measuring up to 1.5 $3 \mathrm{~m}$ in length and about $22-28 \mathrm{~cm}$ in diameter at the base. The stem then divides into smaller branches measuring $17-20 \mathrm{~m}$ in length and $10-15 \mathrm{~cm}$ in diameter that continue growing horizontally and/or vertically climbing on nearby supports (Fig. 2: I, II). The branching is monopodial and the branches bear pairs of revolute tendrils, petioles, leaves and/or inflorescences. Old branches (Fig. 3: I) are cylindrical, grayish brown, woody showing rough, fissured and cracked surface. Younger branches are flexible, green, densely hairy, $0.5-1 \mathrm{~cm}$ in diameter, cylindrical (deeply grooved when very young), climbing using numerous pairs of tendrils and break with fibrous fracture (Fig. 3: II). In addition to number and fertility of stamens, presence of tendrils targeted the morphological segregation of $B$. vahlii to genus Phanera (Wunderlin, 2010). 


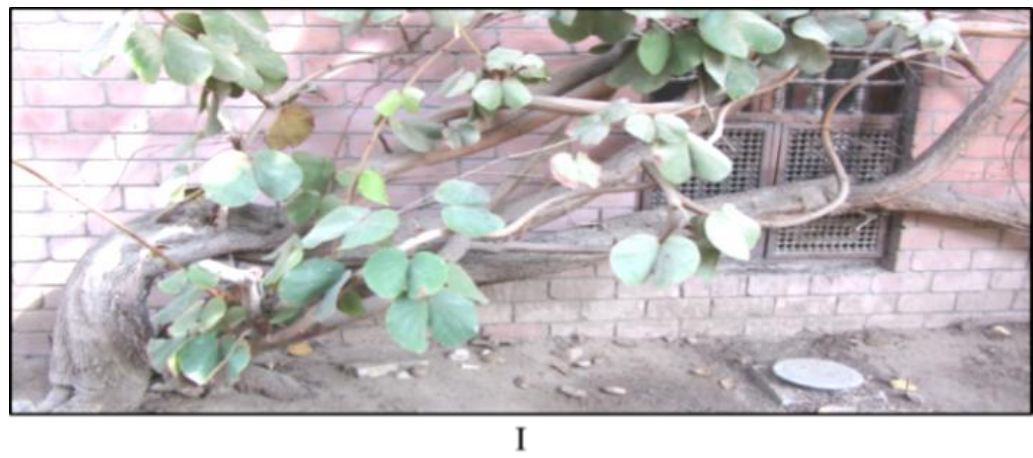

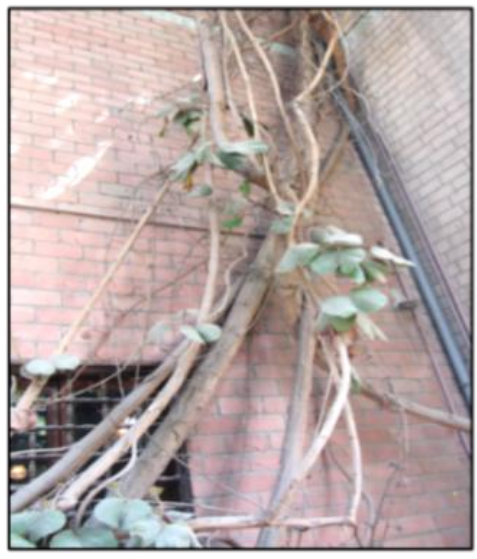

II

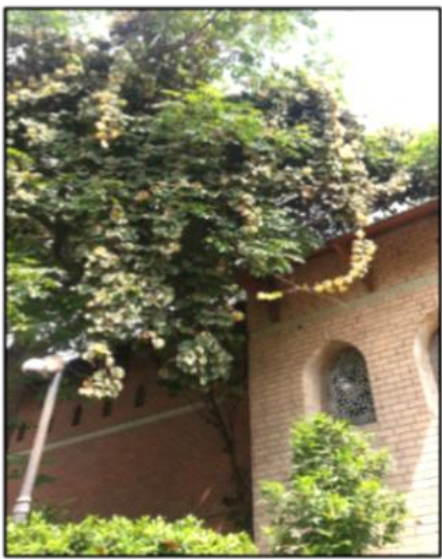

III

Fig. 2: Photographs of the climbing tree of B. vahlii

I: The trunk, II:Smaller branches supporting on walls, III:Leafy and flowering branches.

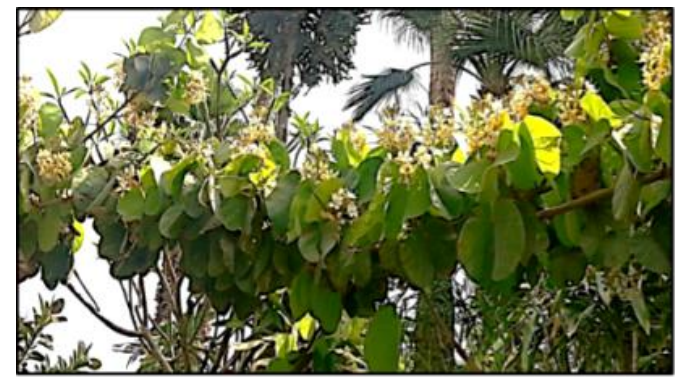

$\mathrm{I}-\mathrm{a}$

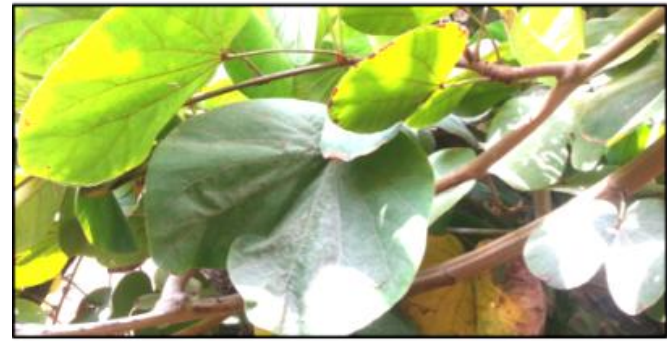

$\mathrm{I}-\mathrm{b}$

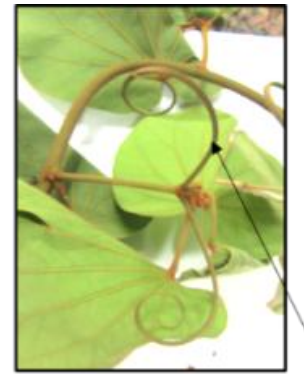

II-a

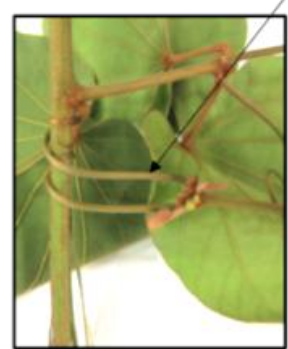

II-b

Fig. 3: Photographs of the smaller branches and revolute tendrils of B. vahlii I: Old leafy and flowering branches, II:A pair of coiled revolute tendrils. 


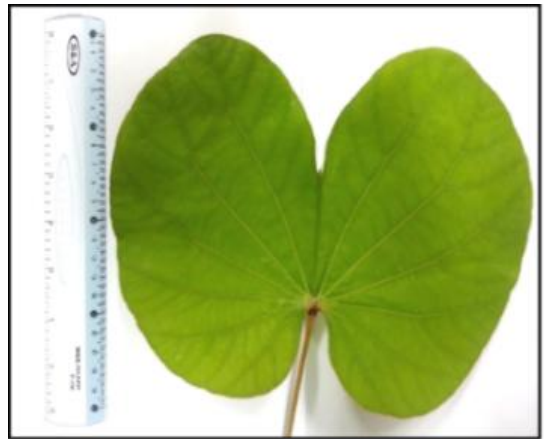

I

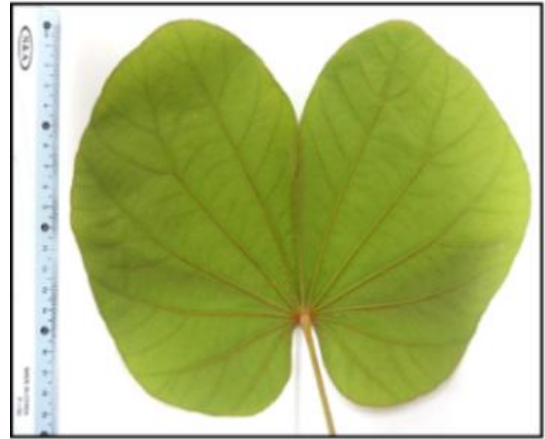

II

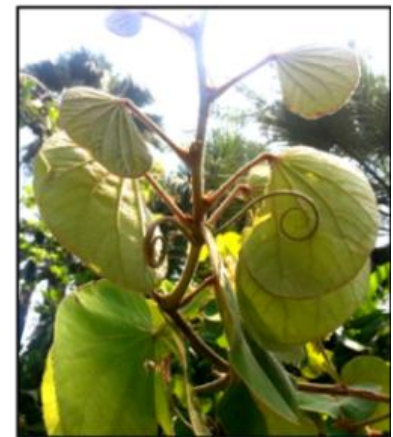

III

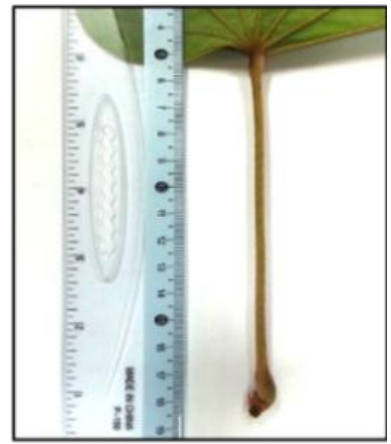

IV

Fig. 4: Photographs of the leaves of $B$. vahlii and their phyllotaxis I: Upper surface, II: Lower surface, III: Alternate phyllotaxis, IV: Petiole.

\section{The leaf (Fig. 4)}

As other Bauhinia plants, the leaves are evergreen, cauline, alternate, simple, petiolate and exstipulate but being larger than other species measuring $15-45 \mathrm{~cm}$ in length and almost as broad with an entire margin. The lamina is $8-30 \mathrm{~cm}$ long, orbiculate in shape with cordate base and deeply lobed apiculate apex divided from third to half way down into two obtuse lobes giving the common shape of Bauhinia plants; camel's foot. The upper surface is hairy and green in color being darker than the lower one, whereas the lower surface is densely hairy. The leaves show palmate reticulate venation usually 11-15 nerved with the midrib prominent to the lower surface. The petiole is long, cylindrical, green, densely hairy, measures $7-15 \mathrm{~cm}$ in length and $3-4 \mathrm{~mm}$ in diameter with a swollen base (pulvinate) and so is its apex.

\section{Anatomical features of Bauhinia vahlii Wight \& Arnott. The stem (Fig. 5 and 6)}

B. vahlii stem was subjected to a detailed histological study in both its old and younger stages in addition to the powdered form.

\section{Old stem (Fig.5: I-VI)}

A transverse section in the stem is circular in outline and revealed the normal stem layers starting with the outer tegumentary tissue which indicated that the stem sample was in the early stages of cork formation. It starts with a single layer of epidermal cells with rare paracytic stomata and numerous bases of broken hairs followed by 4-6 rows of radially arranged rectangular cells with suberized walls at different stages of thickening, the cork. The cortex consists of 12-15 rows of rounded parenchyma cells interrupted with numerous irregularly shaped lignified sclereids and followed by a pericyclic layer formed of alternating patches of lignified fibers and sclereids interrupted with parenchyma cells. The vascular tissue consists of a complete ring of an open collateral vascular bundle traversed by uniseriate medullary rays with dark reddish brown content. The phloem consists of phloem elements formed of sieve tubes, companion cells and phloem fibers. The xylem appears as two distinct zones where the outer one is formed mainly of wood parenchyma and few lignified xylem vessels. On the other hand, the inner zone is formed mainly of lignified xylem elements; vessels, tracheids, wood fibers and little wood parenchyma. The vessels are mainly wide with bordered pitted thickening and slit like openings in addition to few narrow vessels showing spiral thickening. Tracheids are few with lignified bordered pitted walls and blunt ends. Wood parenchyma is rectangular in shape with pitted lignified walls. The pith is a moderately narrow four armed parenchymatous zone of large rounded cells. All the fibers in the section are lignified and accompanied by parenchyma cells containing prisms of calcium oxalate. These prisms were also detected in some cells of both the cortex and pith layers with the later having in addition $\mathrm{Ca}$ oxalate clusters. 


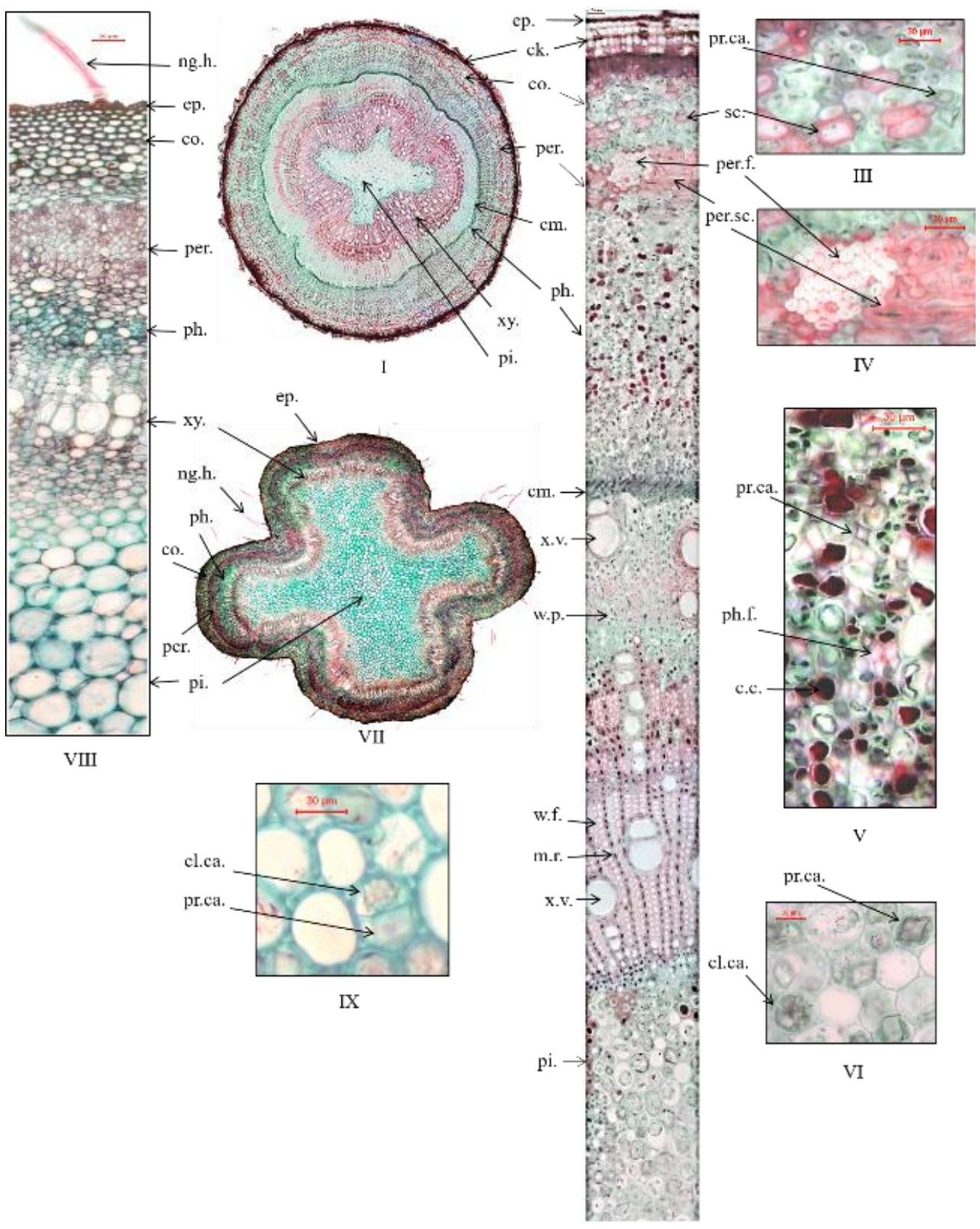

II

Fig. 5: Photographs of transverse sections in two stages of B. vahlii stem.

I: T.S. in an old stem (low power), II: T.S. in an old stem (high power), III: cortex of old stem, IV: pericyclic fibers and sclereids, V: phloem of old stem, VI: pith of old stem, VII: T.S. in a younger stem (low power), VIII: T.S. in a younger stem (high power), IX: pith of a younger stem.

c.c., colored content; ck., cork; cl.ca., cluster of Ca oxalate; cm., cambium; co., cortex; ep., epidermis; m.r., medullary ray, ng.h., non-glandular hair; per., pericycle; per.f., pericyclic fiber; per.sc., pericyclic sclereids; ph., phloem; ph.f., phloem fiber; pi., pith; pr.ca., prism of Ca oxalate; sc., sclereids; w.f., wood fiber; w.p., wood parenchyma; xy., xylem; x.v., xylem vessel.

\section{Younger stem (Fig. 5: VII-IX)}

Histological investigation of younger stem samples showed the same layers of the old one with some differences. The stem is four armed or cross shaped in outline with much narrower phloem and xylem tissues and a wider pith. It was also devoid of outer cork layer with the presence of polygonal epidermal cells instead with rare paracytic stomata and numerous non-glandular tetracellular uniseriate hairs arising from cicatrices. The hairs resemble the common type in Papilionoideae with small basal cells and an elongated distal one and that are of rare occurence in Caesalpinoideae (Metcalfe and Chalk, 1950, Solereder, 1985). The sclereids traced in both cortical and pericyclic layers of the old sample were absent and so the colored content detected in the medullary rays. 


\section{Powdered stem (Fig. 6)}

Powdered stem is greenish brown in color, odorless and tasteless. Microscopically, it is characterized by presence of elements discussed in the sections including polygonal axially elongated epidermial cells with straight anticlinal walls covered with smooth cuticle showing rare paracytic stomata and nonglandular hairs, non-glandular tetracellular uniseriate hairs with three small basal cells and an elongated terminal one arising from cicatrices and usually appear devoid of one or more of their basal cells, lignified fibers and sclereids, few lignified spiral xylem vessels and numerous lignified wide bordered pitted vessels with slit like openings, bordered pitted lignified tracheids, wood parenchyma cells, numerous bundles of fibers accompanied by parenchyma cells containing prisms of calcium oxalate, numerous scattered clusters and prisms of calcium oxalate. The measurements of elements detected are represented in Table $\mathbf{1 .}$
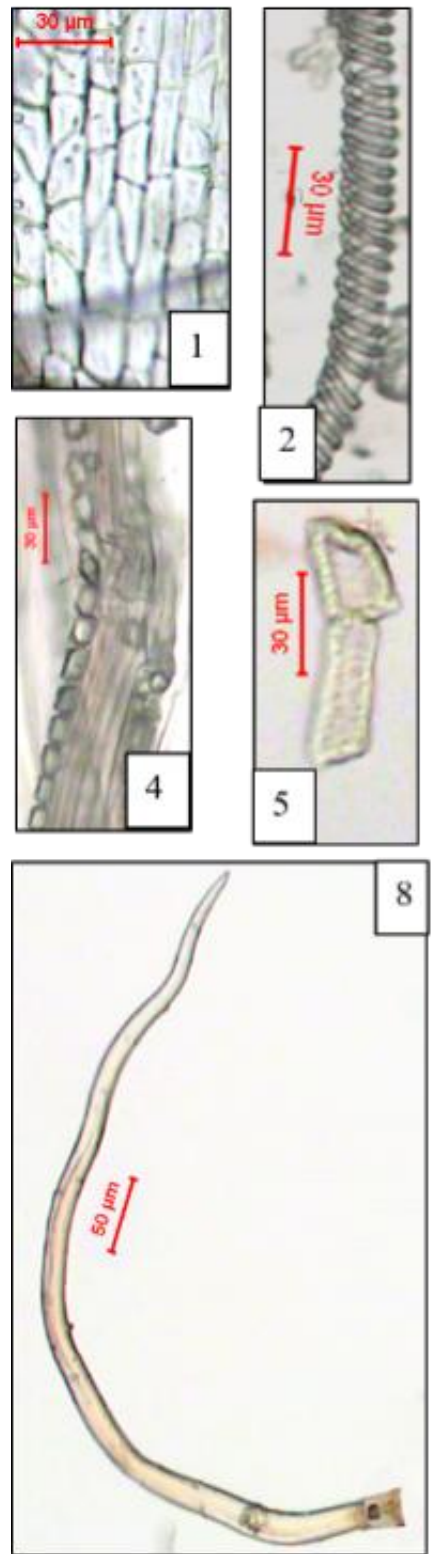
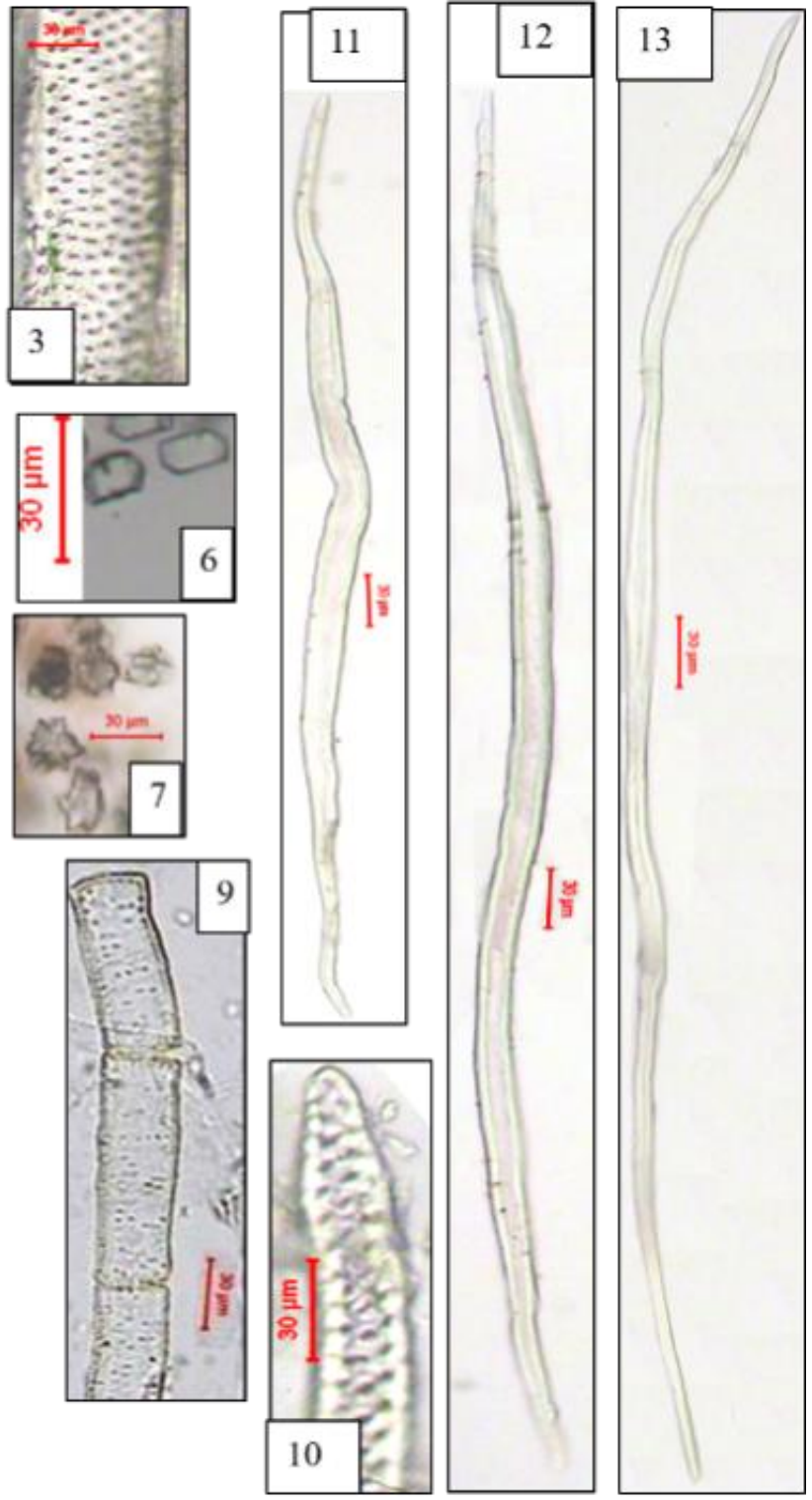

Fig. 6: Photographs of different elements in powdered B. vahlii stems.

1: epidermal cells, 2: spiral xylem vessels, 3: boardered pitted vessels, 4: fibers accompanied by cells with prisms of Ca oxalate, 5: sclereids, 6: prisms of Ca oxalate, 7: clusters of Ca oxalate, 8: non-glandular hair, 9: wood parenchyma, 10: tracheids, 11: wood fiber, 12: phloem fiber, 13: pericyclic fiber. 
Table 1: Dimensions of leaf and stem elements of Bauhinia vahlii (in microns).

\begin{tabular}{|c|c|c|c|c|}
\hline Elements & Length & Width & Height & Diameter \\
\hline \multicolumn{5}{|c|}{ Leaf } \\
\hline Upper epidermis & $20-32-44$ & $12-16-24$ & $10-13-17$ & \\
\hline Stomata & $15-\overline{20}-22$ & $9-\underline{10}-12$ & & \\
\hline Lower epidermis & $17-27-30$ & $13-20-22$ & $8-\underline{12}-13$ & \\
\hline Stomata & $13-\overline{17}-20$ & $9-\overline{13}-15$ & & \\
\hline Neural epidermis & $14-\overline{22}-28$ & $6-\underline{13}-16$ & $6-\underline{7.5}-8.5$ & \\
\hline Petiole epidermis & $13-\overline{17}-18$ & 3-7-9 & $7-\overline{12}-13$ & \\
\hline Non-glandular hairs & $160-9 \overline{00}-1150$ & $14-\overline{21}-26$ & & \\
\hline Palisade cells & $28-\underline{30}-45$ & $8-\overline{9-15}$ & & \\
\hline Pericyclic fibers (Lamina) & $520-\overline{600}-780$ & $11-\overline{1} 4-16$ & & \\
\hline Pericyclic fibers (Petiole) & $833-\overline{860}-890$ & $15-\overline{18}-20$ & & \\
\hline Internal fibers (Petiole) & $650-\overline{790}-825$ & $15-\underline{18}-20$ & & \\
\hline Wood fibers (Lamina) & $440-\overline{455}-462$ & $10-\overline{15}-18$ & & \\
\hline Wood fibers (petiole) & $444-\overline{450}-459$ & $12-\overline{18}-22$ & & \\
\hline Spiral xylem vessels & & & & $9-\underline{10}-11$ \\
\hline Borderd pitted xylem vessels & & & & $40-\overline{-60}-90$ \\
\hline Wood parenchyma & $71-\underline{80}-92$ & $15-17-16$ & & \\
\hline Ca ox. clusters & & & & $13-16-17$ \\
\hline Ca ox. prisms & $15-\underline{19}-21$ & $9-\underline{13}-15$ & & \\
\hline \multicolumn{5}{|c|}{ Stem } \\
\hline Epidermis & $13-\underline{21}-34$ & $8-\underline{10-13}$ & $7-\underline{8}-10$ & \\
\hline Non-glandular hairs & $150-\underline{850}-1200$ & $13-\overline{20}-25$ & & \\
\hline Pericyclic fibers & $665-680-690$ & $8-12-15$ & & \\
\hline Phloem fibers & $650-\overline{710}-750$ & $10-\overline{13}-15$ & & \\
\hline Wood fibers & $490-\overline{520}-550$ & $11-\overline{15}-18$ & & \\
\hline Sclereids & $22-\underline{30}-44$ & $16-\overline{22}-28$ & & \\
\hline Tracheids & & & & $26-\underline{29-31}$ \\
\hline Spiral xylem vessels & & & & $10-\overline{11}-13$ \\
\hline Pitted xylem vessels & & & & $58-\overline{62}-65$ \\
\hline Wood parenchyma & $75-86-98$ & $23-26-28$ & & \\
\hline Ca ox. clusters & & & & $17-26-32$ \\
\hline Ca ox. prisms & $13-15-17$ & $6-9$ & & \\
\hline
\end{tabular}

* The underlined values represent the common measurment of each element.

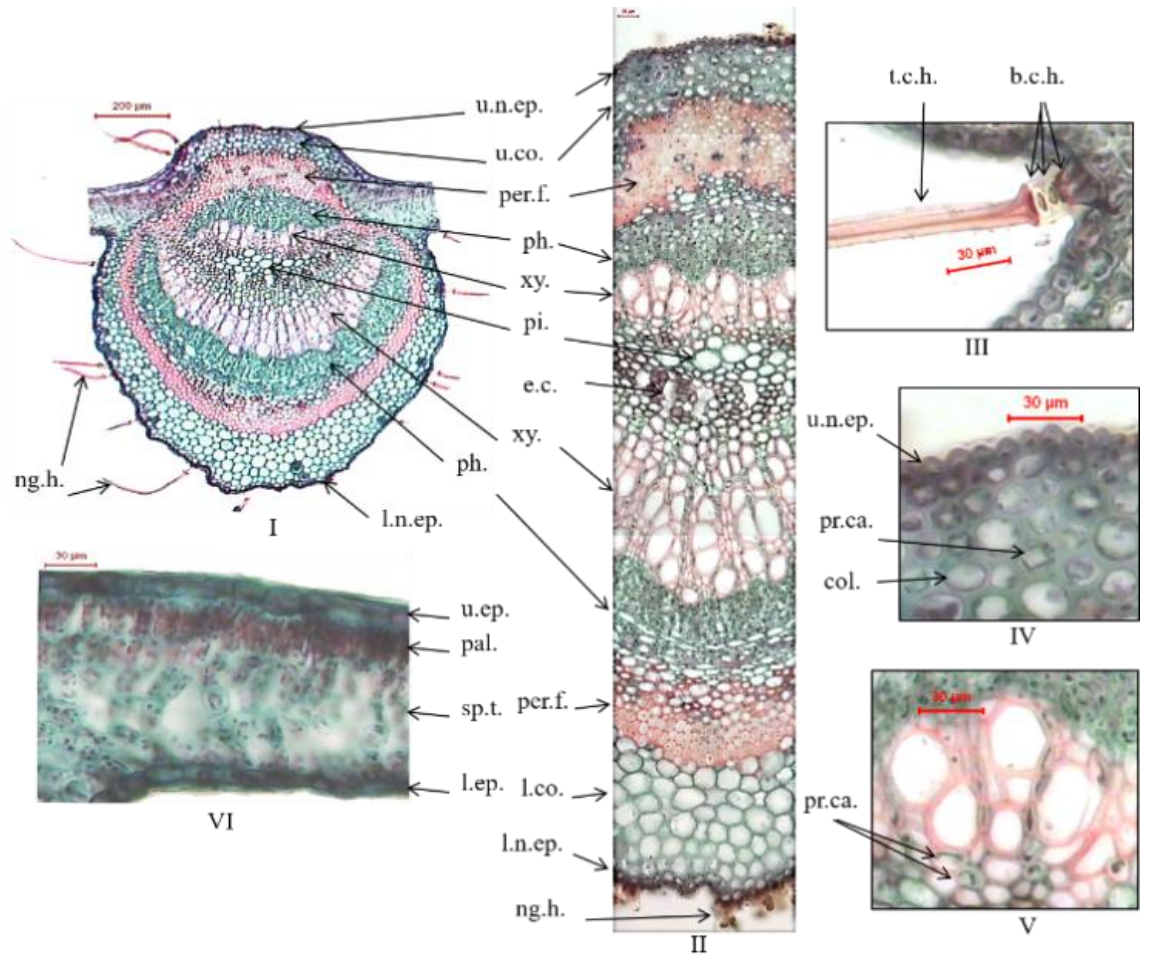

Fig. 7: Photographs of transverse section in leaf lamina of B. Vahlii.

I: T.S. in midrib region (low power), II: T.S. in midrib region (high power), III: epidermis with hair, IV: cortex layer, V: xylem, VI: T.S. in lamina region.

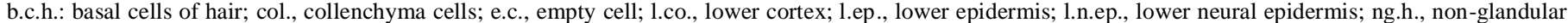

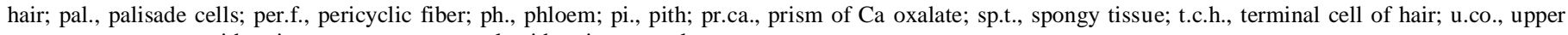
cortex; u.ep., upper epidermis; u.n.ep., upper neural epidermis; xy., xylem 


\section{The leaf (Fig. 7, 8 and 9)}

Bauhinia vahlii Wight \& Arnott. leaf was subjected to a detailed study including the lamina, the petiole and the powdered form.

\section{The lamina (Fig. 7)}

A transverse section in the leaf lamina shows upper and lower epidermises enclosing a discontinuous dorsiventral mesophyll and 3-5 rows of irregularly shaped parenchyma cells with large intercellular spaces of its spongy tissue. Both epidermises consist of polygonal slightly elongated to isodiametric cells with slightly thickened wavy (upper surface) and somewhat straight (lower surface) anticlinal walls covered with smooth cuticle. Paracytic stomata are very few, if any, on the upper surface but more abundant on the lower one. Also, the hairs are found on both surface but being dense on the lower surface.

The neural epidermis consists of polygonal axially elongated sub-papillosed cells with straight slightly thickened anticlinal walls, covered with smooth cuticle, devoid of stomata and showing numerous non-glandular hairs arising from cicatrices. All the hairs are similar to those of the stem and that are rare in Caesalpinoideae. The midrib is more prominent to the lower surface and the meristele is formed of two unequal collateral vascular bundles; an upper small inverted bundle and a lower large cresent shaped one, enclosing central pith and surrounded by a continuous ring of lignified pericyclic fibers. The upper cortex is mainly 5-6 rows of collenchyma cells occasionally contain minute starch granules, tannins and prisms of calcium oxalate, while the cortex under the lower epidermis consists mainly of 2-3 rows of collenchyma cells followed by 5-6 rows of large parenchyma cells with few irregularly shaped cells. The xylem and phloem elements are similar to those of the stem with the later being devoid of fibers and may contain clusters of $\mathrm{Ca}$ oxalate. Both pericyclic and xylem fibers are accompanied by parenchyma cells containing prisms of calcium oxalate. The core tissue, the pith as named by Solereder (1985), consists of rounded thin walled parenchyma cells with some cells being large, empty (not stained with all tested reagents) and irregularly shaped with wavy walls.
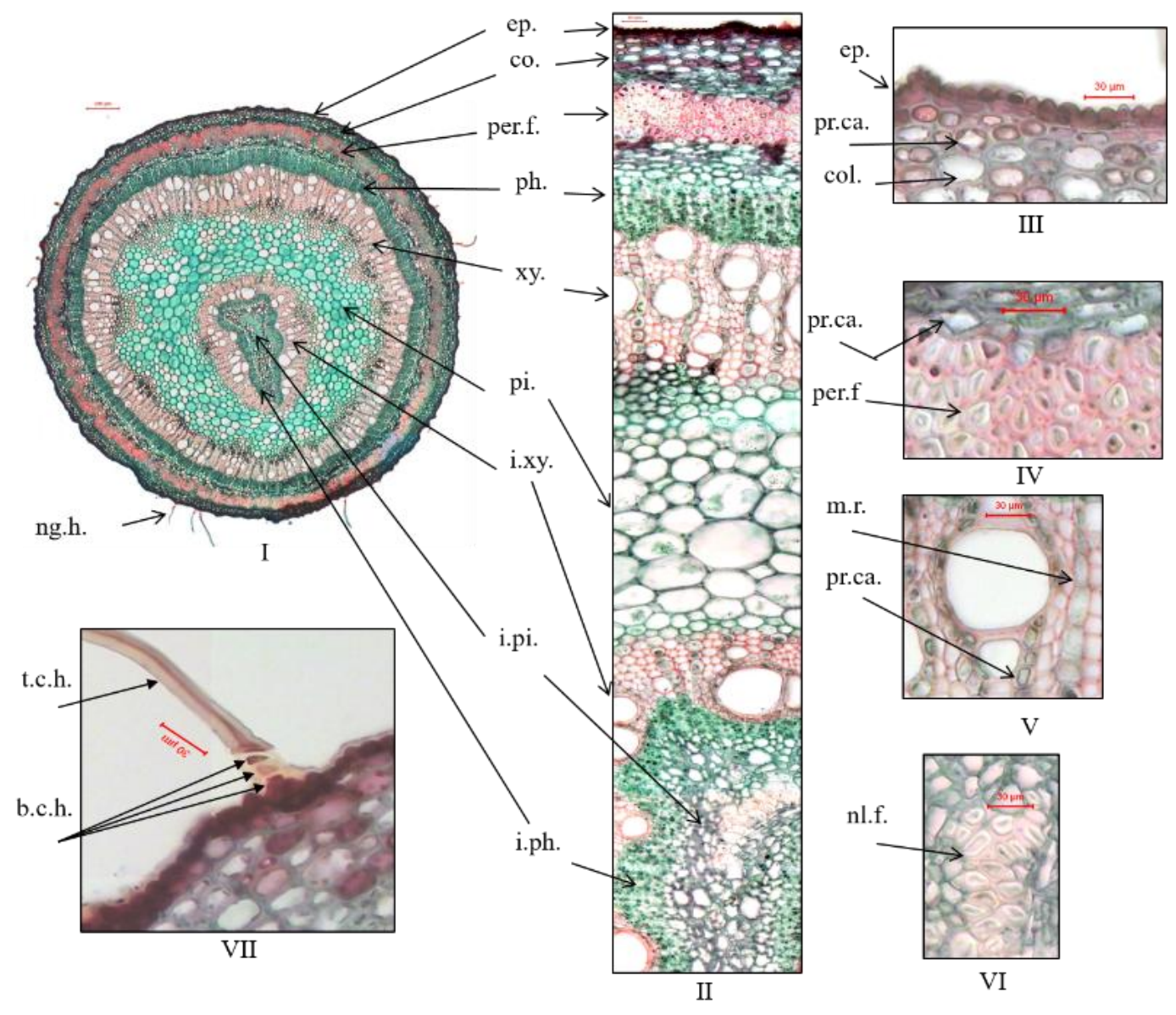

VI

Fig. 8: Photographs of transverse section in leaf petiole of $B$. vahlii.

I: T.S. in petiole (low power), II: T.S. in petiole (high power), III: cortex layer,IV: pericycle, V: xylem, VI: pith, VII: epidermis with hair.

b.c.h.: basal cells of hair; co. cortex; col., collenchyma cells; ep., epidermis; i.ph., inner phloem; i.pi., inner pith; i.xy., inner xylem; m.r., medullary ray; ng.h.: non glandular hair; nl.f., non-lignified fiber; per.f., pericyclic fiber; ph., phloem; pi., pith; pr.ca., prism of Ca oxalate; t.c.h.: terminal cell of hair; xy., xylem. 


\section{The petiole (Fig. 8)}

The petiole section is circular in outline and is formed of an epidermal layer followed by 7-9 rows thick colenchymatous cortex and a continuous ring of lignified pericyclic fibers enclosing a circular vascular tissue consisting of an open collateral vascular bundle traversed by uniseriate medullary rays and enclosing a pith with an internal inverted vascular bundle. The epidermis consists of polygonal slightly elongated sub-papillosed cells with thick straight anticlinal walls covered with smooth cuticle and shows both stomata and non-glandular hairs similar to those of the lamina. The main vascular bundle composition is similar to that of the stem. The pith consists of 10-12 rows of large rounded parenchyma cells with narrow intercellular spaces and shows a large central inverted vascular bundle with an outer layer of xylem elements followed by inner phloem layer. The internal pith consists of 3-5 rows of irregular parenchyma cells with patches of non-lignified fibers embedded within. All the the other fibers are lignified and accompanied by cells with prisms of $\mathrm{Ca}$ oxalate. The prisms are detected in the whole petiole layers and the pith may have clusters in addition.

\section{Powdered leaf (Fig. 9)}

Powdered leaf is green in color, with characteristic nonaromatic odor and taste. It is characterized microscopically by presence of upper and lower leaf epidermises, neural epidermis, petiole epidermal cells, non-glandular tetracellular uniseriate hairs with three small basal cells and an elongated terminal one arising from cicatrices where they usually appear devoid of one or more of the basal cells, palisade cells, lignified fibers, lignified narrow spiral and wide bordered pitted xylem vessels, numerous bundles of fibers accompanied by parenchyma cells containing prisms of calcium oxalate, wood parenchyma cells and numerous scattered clusters and prisms of calcium oxalate.The measurements of different elements detected are summarized in Table 1.
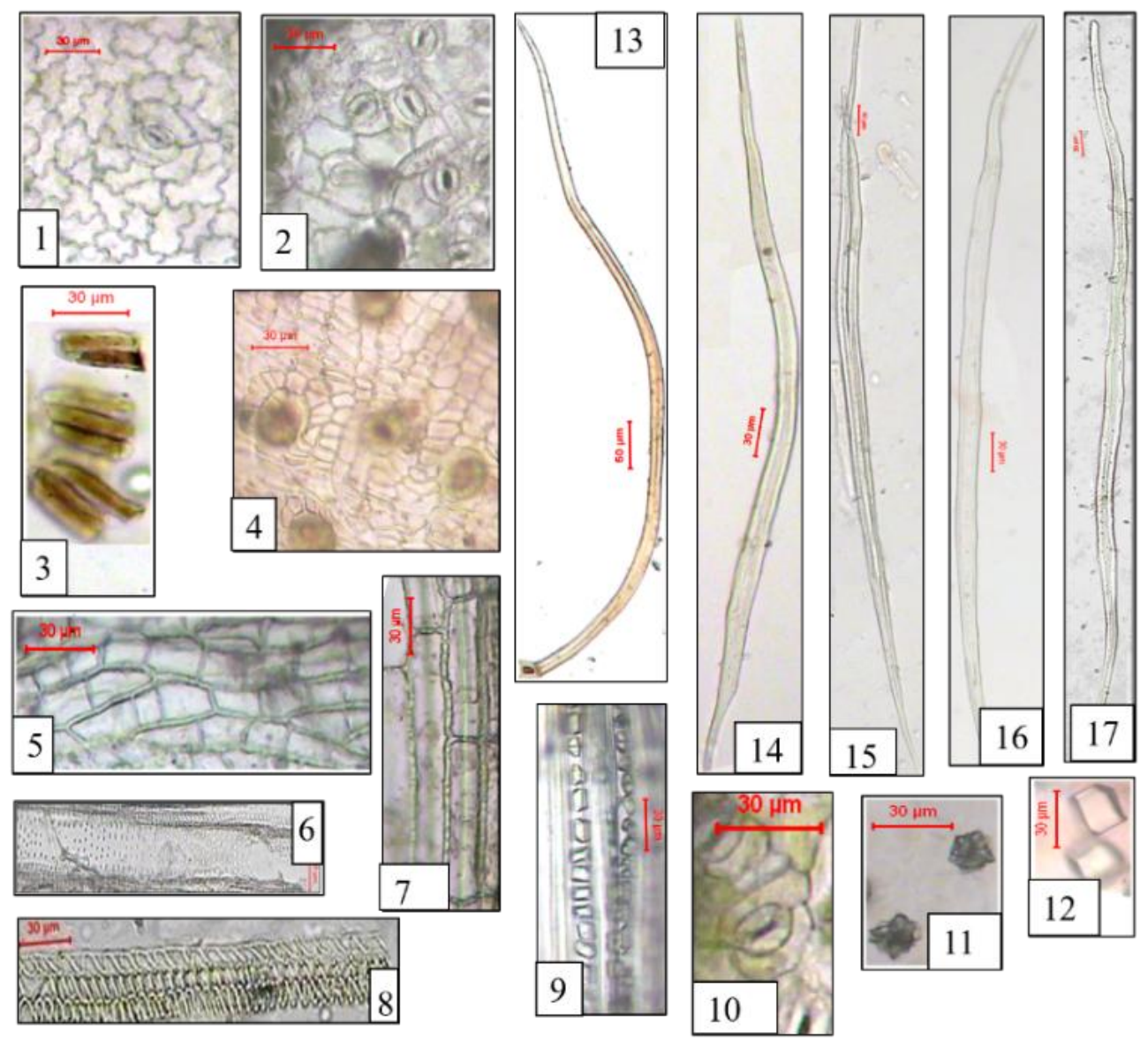

Fig. 9: Photographs of different elements in powdered B. vahlii leaves

1: upper epidermal cells, 2: lower epidermal cells, 3: palisade cells, 4: petiole epidermal cells and cicatrices, 5: neural epidermal cells, 6: bordered pitted xylem vessels, 7: wood parenchyma, 8: spiral xylem vessel, 9: fibers accompanied by prisms of Ca oxalate, 10: paracytic stomata, 11: clusters of Ca oxalate, 12: prisms of Ca oxalate, 13: non-glandular hair, 14: wood fiber, 15: non lignified fiber of petiole, 16: leaf pericyclic fiber, 17: petiole pericyclic fiber. 


\section{CONCLUSION}

Bauhinia vahlii Wight \& Arnott. is a huge climber with recently evidenced anti-oxidant, antihyperglycemic and antiinflammatory effects. It can be differentiated from other Bauhinia species by its climbing growth, its very large camel's foot shaped leaves, large white flowers with three long fertile stamens and two short staminodes in addition to numerous pairs of revolute coiled tendrils supporting its climbing on its branches or neighbor plants. Microscopically, the leaves and stems are characterized by the long non-glandular hairs with three small basal cells and elongated distal one that are rare in Caesalpinoideae (Metcalfe and Chalk, 1950, Solereder, 1985). The leaf's lamina shows a central pith with large empty cells with irregular walls and its petiole has an extra inverted vascular bundle embedded within the pith. Due to the tendrils and nature of the flower's androceum, B. vahlli was recently segregated into a separate genus, Phanera, a treatment that matches the phylogenetic reclassification of many Bauhinia plants reported by Sinou et al. (2009).

\section{Financial support and sponsorship: Nil.}

Conflict of Interests: There are no conflicts of interest.

\section{REFERENCES}

Allen ON and Allen EK. 1981. The Leguminosae: A source book of characteristics, uses and nodulation. USA, Wisconsin: UW Press.

Baily LH. 1953. The standard cyclopedia of horticulture. New York: The Macmillan Company.

Bandyopadhyay S. Comments on the type of Bauhinia vahlii Wight \& Arn.(Leguminosae: Caesalpinioideae). Candollea, 2008; 63(1): 35-37.

Cechinel Filho V. Chemical composition and biological potential of plants from the genus Bauhinia. Phytother Res, 2009; 23(10): 1347-54.

Das SN, Jagannath PV, Dinda SC. Evaluation of AntiInflammatory, Anti-diabetic activity of Indian Bauhinia vahlii (stembark). Asian Pacific Journal of Tropical Biomedicine, 2012; 2(3): 1382-87.
Elbanna AH. 2015. A Pharmacognostical study of Bauhinia vahlii Wight \& Arnott family Fabaceae Growing in Egypt. Master thesis, Cairo University.

Elbanna AH, Mahrous EA, Khaleel AE, El-alfy TS. Chemical investigation of Bauhinia vahlii Wight \& Arnott. leaves grown in Egypt. International Journal of Pharmacy and Pharmaceutical Sciences, 2016; 8(6): 269-72.

Fernald ML. 1970. Gray's Manual of Botany. New York: D. Van Nostrand Company.

Kraus JE, Arduin M. 1997. Basic manual methods in plant morphology. Edur Rio de Janeiro.

Metcalfe C, Chalk L. 1950. Anatomy of the dicotyledons, Vol. 2. 1950 .

Parrotta JA. 2001. Healing plants of peninsular India. New York, USA,: CABI publishing.

Sambamurty A. 2005. Taxonomy of angiosperms. IK International Pvt Ltd.

Samuel BJ, Arlene EL. 1979. Plant Systematics. New York: McGraw-Hill Book Company.

Sinou C, Forest F, Lewis GP, Bruneau A. The genus Bauhinia sl (Leguminosae): a phylogeny based on the plastid trn L-trn $\mathrm{F}$ region. Botany, 2009; 87(10): 947-60.

Solereder H. 1985. Systematic anatomy of the dicotyledons. Oxford: The Clarendon Press.

Sowndhararajan K, Kang SC. Free radical scavenging activity from different extracts of leaves of Bauhinia vahlii Wight \& Arn. Saudi J Biol Sci, 2013; 20(4): 319-25.

Wight R and Arnott GAW. 1834. Prodromus Florae Peninsulae Indiae Orientalis: containing abridged descriptions of the plants found in the peninsula of British India, arranged according to the natural system. Parburg.

Wunderlin RP. 2010. Reorganization of the Cercideae (Fabaceae: Caesalpiniodeae). Guy L. Nesom.

\section{How to cite this article:}

Elbanna AH, Mahrous EA, Khaleel AE, El-alfy TS. Morphological and anatomical features of Bauhinia vahlii Wight \& Arnott. grown in Egypt. J App Pharm Sci, 2016; 6 (12): 084-093. 